\title{
Late Weichselian deglaciation pattern in the southwestern Baltic: Evidence from glacial deposits off the island of Møn, Denmark
}

\author{
JØRN BO JENSEN
}

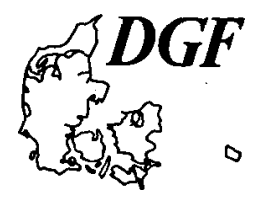

Jensen, J.B.: Late Weichselian deglaciation pattern in the southwestern Baltic: Evidence from glacial deposits off the island of Møn. Denmark. Bulletin of the Geological Society of Denmark, Vol. 40, pp. 314-331. Copenhagen, 1993-12-30. https://doi.org/10.37570/bgsd-1993-40-15

Shallow seismic investigations and sediment sampling were carried out in the Hjelm and Fakse Bugt (Bay) off the island of Møn, Denmark.

Ribbed moraine morphology is observed in the Hjelm Bugt area while results from seismic studies in Fakse Bugt reveal two different late-glacial sequences: 1; glacial diamict and 2; proglacial, delta - ice lake and fluvial deposits. These deposits originate from the final Late Weichselian deglaciation.

Within sequence 1 two units can be distinquished. Unit 1 .a consists of glacial deposits dislocated by thrusting that form asymmerical ridges on the sea floor, unit 1 . $b$ is not pre-consolidated, (soft) diamict interpreted as supraglacial flow diamict.

Sequence 2 can likewise be subdivided in two units $a$ and $b$. These can be character-ized as delta deposits formed in a glacial lake in which a sudden lowering of the water-level caused a break of the sedimentation.

Earlier studies from the Skåne area (southern Sweden) report a similar depositional pattern during deglaciation. The deposits consist here of asymmetrical ridges, in-terpreted as Rogen moraines. They were resting on and covered with flow diamict deposits and water layered deposits, thought to have been formed by an arctic glacier with a cold-based compressive marginal zone.

From the comparison of onshore glaciotectonic and morphological data with the offshore data presented, it is concluded that the Møns Klint cliff section was formed under glaciotectonic compression between two ice lobes, one from a north-eastern and another from a south-eastern direction. The formation of Møns Klint was thus associ-ated with a final Weichselian readvance.

Jøm Bo Jensen, Geological Survey of Denmark, Thoravej 8, DK-2400 Copenhagen NV. January 1st, 1992.

\section{Introduction}

In Denmark investigations of the Late Pleistocene deglaciation pattern have had a long tradition. In the earliest works one single glaciation was assumed (Ussing 1899). Later more consistently multi glacial theories (Rørdam 1893, 1909, Milthers 1909, Madsen, Jessen \& Nordman 1928, Andersen 1933, Hansen 1965, Berthelsen 1978, Sjørring 1983, Houmark-Nielsen 1987) have been put forward to explain the complicated depositional story of the Pleistocene deposits. The various theories has been established by using a variety of methods, traditionally including morphological, lithological, perographical, pa- lynological and paleontological studies. In the last couple of decades absolute dating, kineto-stratigraphical and geophysical studiès have also been used in increasing degree.

Seismic surveys have systematically been carried out in the shallow Danish waters for about 10 years, with the purpose to map natural resources mainly sand and gravel usable in the Danish building industry. The present paper focuses on these kind of marine shallow reflection seismic data from Hjelm Bugt and Fakse Bugt near the Island Møn, SE Denmark (Fig. 1). The data will be compared with relevant published onshore data in order to describe in more detail the regional Late - Weichselian deglaciation pattern. 


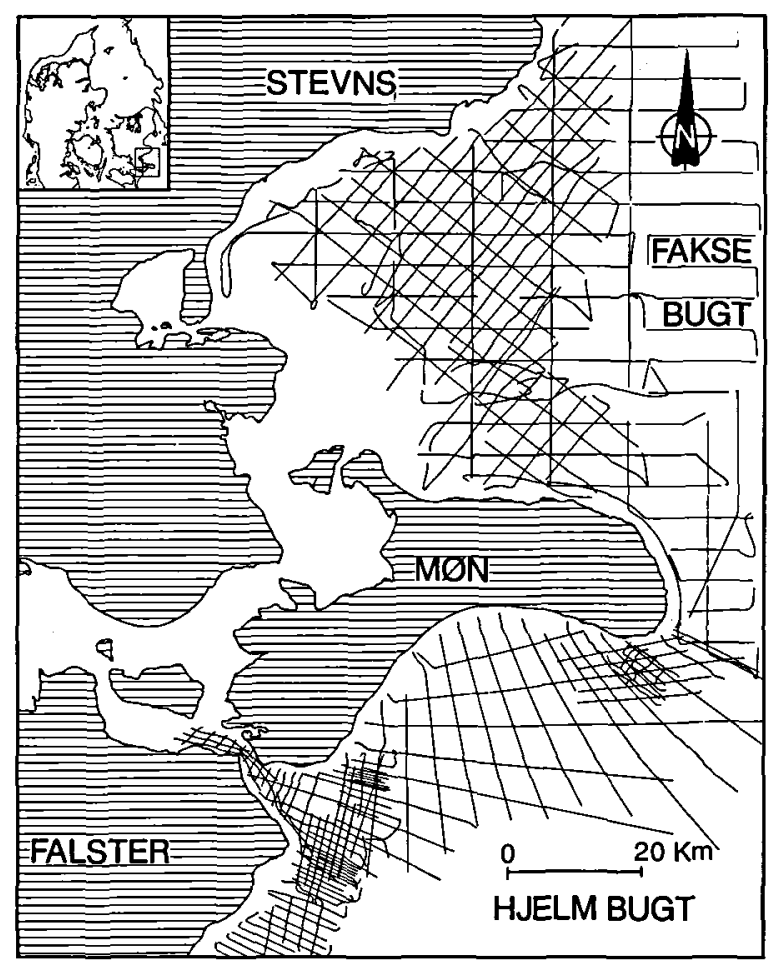

Fig. 1. Survey map showing the Hjelm Bugt and Fakse Bugt seismic grid.

\section{Previous investigations}

A complex Pleistocene geological development, of the Møn onshore area has been described by numerous geologists. Especially the famous Møns Klint (klint = cliff) section has attracted much attention, already described by one of the pioneers of geological studies in Denmark Forchhammer (1835). Later on more competent conclusions were put forward by Johnstrup (1873), who explained the displacements in the cliff section as results of lateral pressure caused by the movement of the inland ice. This interpretation was supported by Slater (1927) but disputed by Hintze (1937), who considered orogenic tectonic movements an appropriate cause. By detailed comparative studies at Møn and Rügen, Gripp (1947) succeeded in relating the dislocated white chalk deposits (floe system) to a glaciotectonic compression pattern formed between two ice lobes moving from a northern and a southern direction. Morphological investigations (Haarsted 1956) confirmed Gripp's interpretation, showing a characteristic ridge pattern consisting of two hill systems, comparable to the floe system in the Møns Klint cliff section. The ice lobes were interpreted to represent recessional stage $\mathbf{H}$ (Hansen \& Nielsen 1960) belonging to the final deglaciation of the Weichselian ice cap. The kineto-stratigraphical concept dealing with a combination of glacial stratigraphy and structural analysis (Berthelsen 1973) renewed the interest for the Møn area (Berthelsen et al. 1977, 1978, 1979, Aber 1979). These studies generally confirmed the Weichselian glaciation pattern introduced by Andersen (1933). However, the formation of ice-thrusted ridges of eastern Møn was attributed to two different events (Berthelsen et al. 1977), i.e. the Main Weichselian Advance (Houmark-Nielsen 1987) contributing with glacial thrusting from north and the younger Belt Sea Readvance with glacial thrusting from a southern direction. A detailed summary of the literature dealing with the Møn area is presented by Hyde (1986) as an introduction to glacial stratigraphical investigations in the area north-west of the classical Møns Klint cliff section. Various papers have, to a large extent, used glaciotectonic features in the interpretation of the glacial stratigraphy. In some papers the genetic character of glacio tectonism has been a subject of special interest (Berthelsen 1979, Aber $1982,1985,1989$ ). Late Weichselian appearance of vegetation in the region (Kolstrup 1982a, 1982b) has been a subject of investigation recently. Finally, Houmark-Nielsen $(1988,1990)$ and Kolstrup \& Houmark-Nielsen (1991) published investigations carried out at the coastal cliffs a few kilometers west of the classical Møns Klint cliff section. These authors present the most complete stratigraphy established in the area.

Apart from Mikkelsen (1949), Jensen (1992) and Jen-

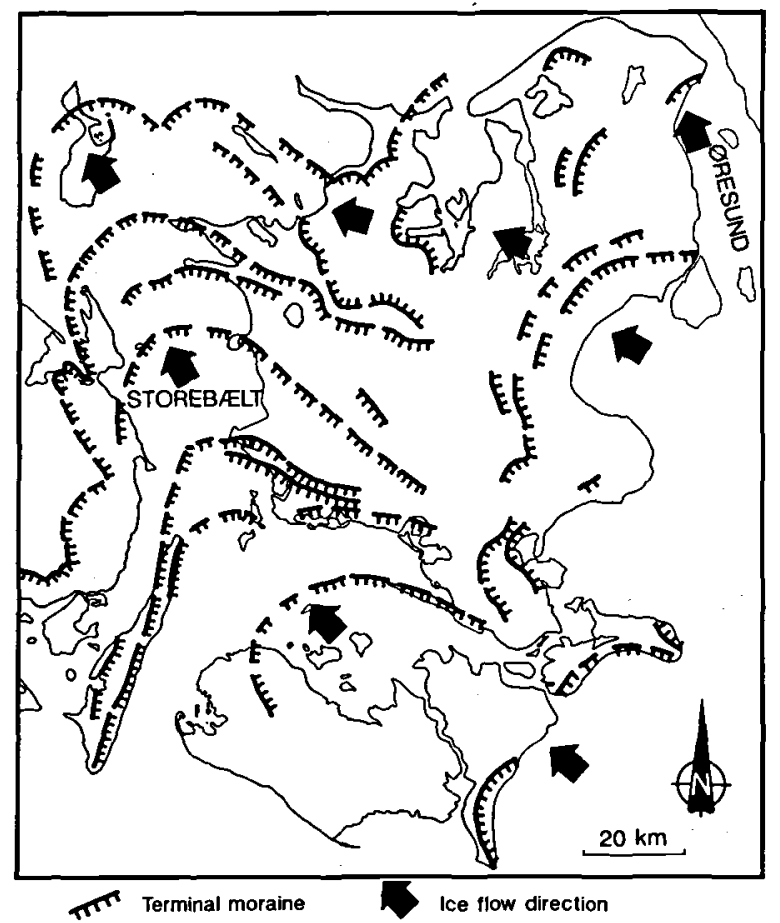

Fig. 2. Distribution of interpreted recessional terminal moraines connected to the final Weischelian deglaciation. Compiled of data from Andersen (1933), Hansen \& Nielsen (1960) and Houmark-Nielsen $(1981,1987)$. 
sen and Stecher (1992), the evolution of the Baltic Ice lake and Holocene water-level changes have only been mentioned in broad terms by various authors.

\section{General setting}

The island of Møn and the surrounding shallow waters reveal a pre-Quaternary surface consisting of Upper Cretaceous chalk and Lower Tertiary limestone (Baartman and Christensen 1975). Coring onshore (Haarsted 1956) and a combination of seismic data and coring in the shallow waters show, that the pre-Quaternary surface can be detected at a regional level between $20 \mathrm{~m}$ and $40 \mathrm{~m}$ below present sea-level (B.S.L.) (Fredningsstyrelsen 1986).

The very thin and occasionally missing Quaternary sediment cover suggests that the pre-Quaternary morphology and possible fault zones may be important factors in the glacial and postglacial development. The Pleis- tocene deposits consist of glacial diamict interlayered by glaciofluvial, glaciolacustrine and marine sediments including the Saalian, Eemian and Weichselian stages (Hintze 1937, Hansen \& Nielsen 1960, Berthelsen et al. 1977, Aber 1979, Hyde 1986, Houmark-Nielsen 1990).

The lowermost unit overlying the pre-Quaternary chalk is a Saalian grey till containing coarse material from the Baltic region (Hyde 1986, Houmark-Nielsen 1990). A thin Eemian marine clayey unit (max. $2 \mathrm{~m}$ ) below the Weichselian deposits is characterized by a shallow water fauna found at several onshore localities in the study area (Petersen and Konradi 1974, Berthelsen et al. 1977, Hyde 1986, Houmark-Nielsen 1990). The Weichselian deposits mainly consist of three different tills interpreted to correlate with the Old Baltic Advance, the Main Weichselian Advance and the Young Baltic Advance as described in the classical Danish Weichselian glacial stratigraphy (Andersen 1933, Hansen 1965, Berthelsen 1978, Sjørring 1983, Houmark-Nielsen 1987). A very prominent stratified clay and sand unit $(0-10 \mathrm{~m}$ thick) can be observed at several localities and has been
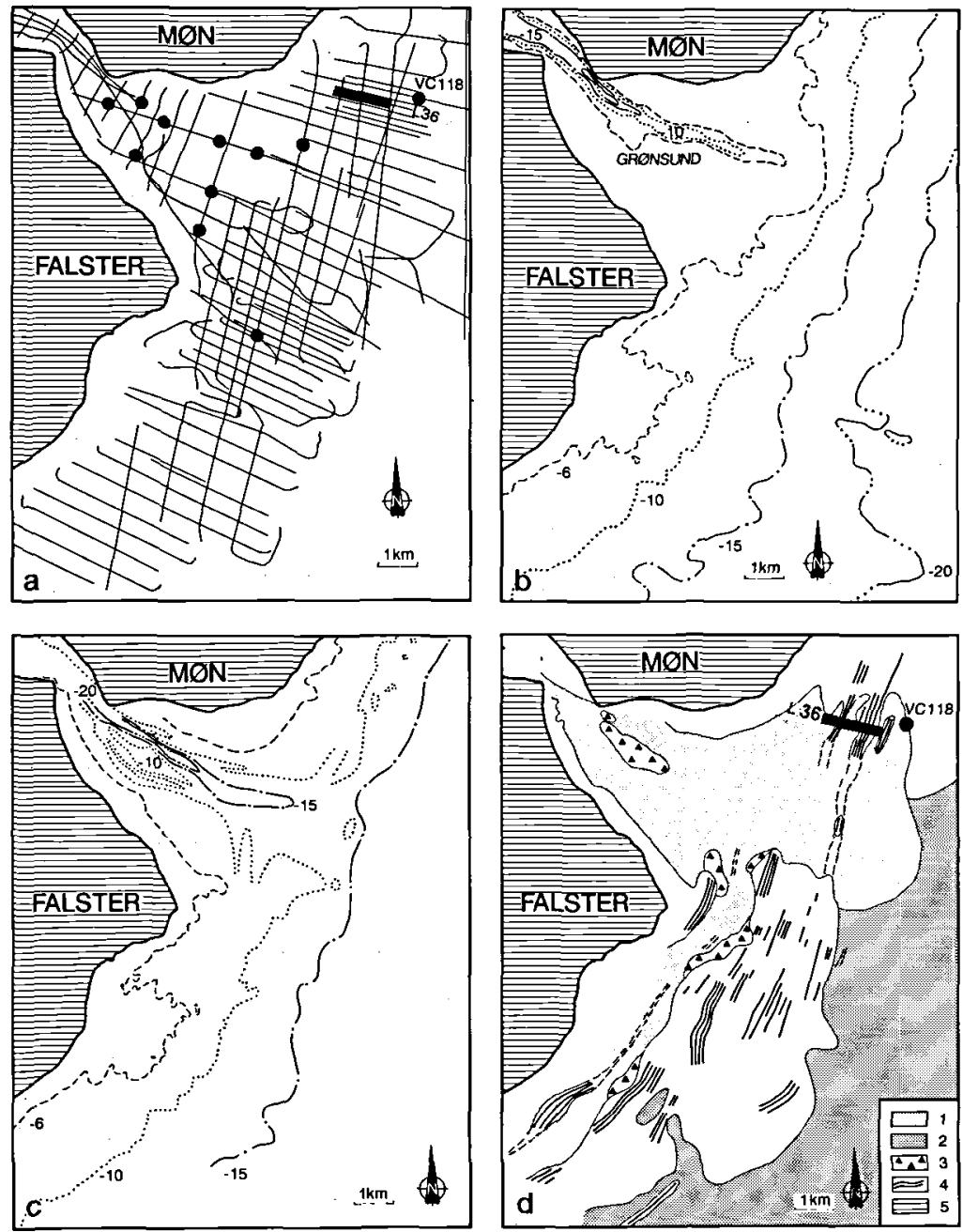

Fig. 3. Hjelm Bugt survey area. a. Seismic grid and vibrocore positions. Seismic example L36 (fig. 4) and vibrocoring VC1 18 are indicated. b. Bathymetric map. c. Surface morphology of glacial deposits. d. Sediment distribution at the sea bed. Seismic example L36 (Fig. 4) and vibrocoring VC118 are indicated. 1: sand, Holocene, 2: clay-sand, Baltic Ice Lake deposits, 3: flow diamict, 4: diamict (till) showing transverse ridges, 5: present land area. 

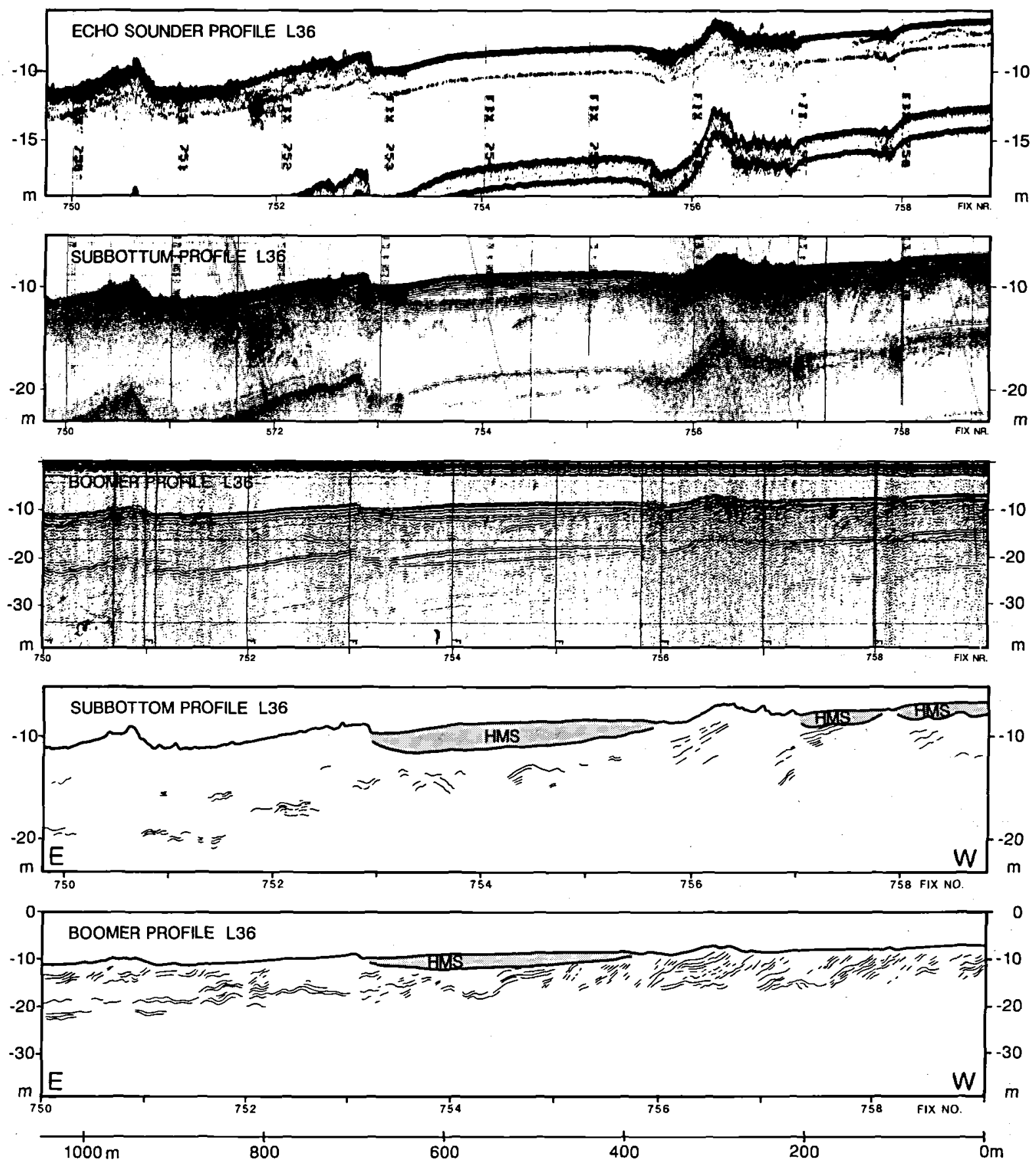

Fig. 4. Shallow seismic profile L36. High frequency echo sounder record (Elac $30 \mathrm{kHz}$ ), subbottom profiler record (ORE $3.5 \mathrm{kHz})$ and Uniboom record (EG\&G $0.8-16 \mathrm{kHz}$ ). The lowermost two profiles show the interpreted Subbottom profile L36 and the interpreted Boomer profile L36.

Thick solid lines indicates "sequence" boundaries and thin solid lines indicates internal reflection pattern. The shaded area (HMS) consists of Holocene Marine Sand. Location of the profile is shown in Fig.3. 

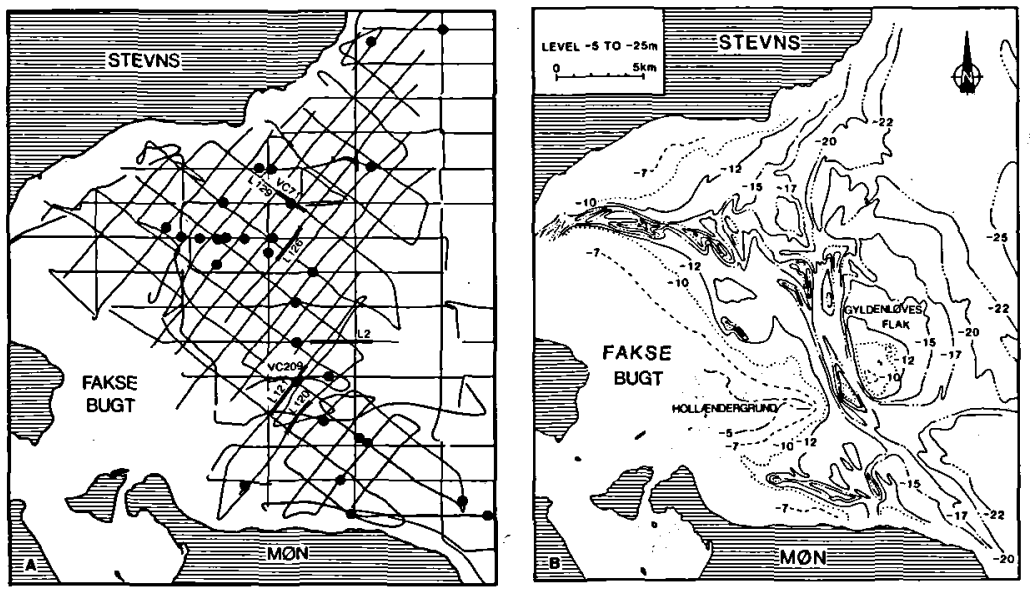

Fig. 5. Fakse Bugt survey area. a. Seismic grid and vibrocore positions. Seismic profiles L2, L120, L121, L126, L129 and vibrocorings VC71, VC209 are indicated. c. Surface morphology of glacial deposits. d. Bathymetric map. d. Sediment distribution at the sea bed. Seismic profiles L2, L120, L121, L126, L129 and vibrocorings VC71, VC209 are indicated.

The seismic stratigraphy is outlined in fig. 6 .

1: gyttja, sequence W.5., 2: sand, sequence W.3.-W.5., 3: flow diamict, sequence 1 unit $b, 4$ : diamict (till) showing transverse ridges, sequence 1 unit a, 5: present coast.
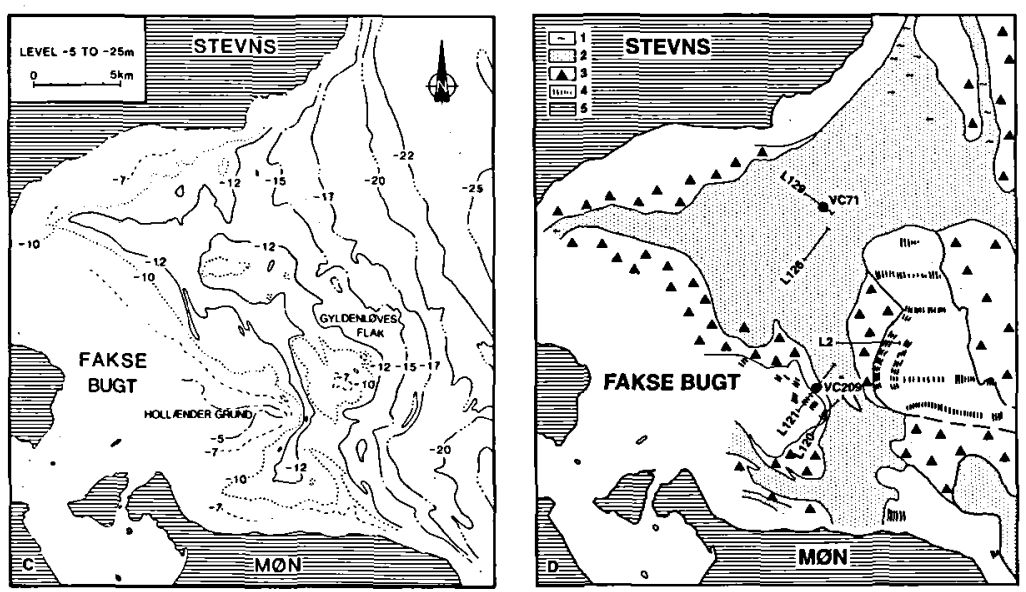

the subject of many discussions relating to age and depositional environment. The latest investigation (Houmark-Nielsen 1990) shows that it represents ice lake deposits probably relating to a major Middle Weichselian ice lake stage. These deposits may be correlated to the glaciolacustrine Grevie Clay found in the Øresund and Kattegat region and interpreted as the Middle Weichselian Kattegat Ice Lake (Lagerlund 1987).

The glaciotectonic evolution is important for the understanding of the stratigraphy in the Møn area. Only limited tectonical imprints can be correlated with the Old Baltic Advance (Berthelsen et al. 1977, Hyde 1986), while prominent glaciotectonic deformations are visible in the south-easternmost part of Møn (Aber 1979, Berthelsen et al. 1977, Berthelsen 1979). These deformations relate to the Main Weichselian Advance, showing deformation from a north-easterly direction. In the easternmost part of Møn only deformations from southeast relating to the Young Baltic Advance are observed (Houmark-Nielsen 1990). The north-easternmost classical part of the Møns Klint section is deformed from a north-eastern to eastern direction. As previously mentioned, early interpretations (Gripp 1947, Haarsted 1956) related all the glaciotectonic deformations in the Møns Klint section to a glaciotectonic compression pattern, formed between two ice lobes moving from a northern and a southern direction during the Late Weichselian stage $\mathrm{H}$ readvance (Hansen \& Nielsen 1960). In later publications, the northern deformation direction was related to the Main Weichselian Advance (Aber 1982, Berthelsen 1979).

The distribution of terminal moraines and sandur deposits connected to the final Weichselian deglaciation (Andersen 1933, Hansen \& Nielsen 1960, HoumarkNielsen 1981, 1987) show an interesting deglaciation pattern. The recessional positions marked by terminal moraines (Fig. 2) reveal two dominating ice lobes, one in the Store Bælt area and another in the Øresund area. These lobes meet in a transitional zone dominated by outwash deposits. During the general glacial retreat they gradually moved from the northwestern part of Sjælland towards Møn, where the ice lobes may have been able to form the floe thrusting as observed in the classical part of the Møns Klint section. 


\section{Data base and methods}

The field work carried out included continuous shallow seismic profiling followed by sediment sampling using vibrocoring, grab sampling, gravity coring and test suction dredging. The study area (Fig. 1) encompasses two different survey areas, i.e. the Hjelm Bugt area and the Fakse Bugt area. The survey in Hjelm Bugt was the first systematical shallow seismic rawmaterial mapping activity in Danish waters carried out by Fredningsstyrelsen (1977). In 1986 it was supplemented by a detailed survey in the Gronsund area (Fig. 3a). In the Fakse Bugt region a similar mapping strategy was chosen, initially following a N-S and E-W general survey grid (1982), which was a framework for a more detailed NE-SW and NW-SE orientated survey grid (1987) (Fig. 5a). The standard shallow reflection-seismic equipment used consisted of the following instruments: High frequency echo sounder (Elac $30 \mathrm{kHz}$ ) suitable for collecting bathymetric data, ORE subbottom profiler $(3.5 \mathrm{kHz})$ giving high resolution data $(0,3 \mathrm{~m}$ vertical resolution) allowing a penetration of maximum $10-30 \mathrm{~m}, \mathrm{EG} \& \mathrm{G}$ Uniboom $(0.8-16 \mathrm{kHz})$ with the possibility of collecting data to a depth of about $50 \mathrm{~m}$ (about $0.5 \mathrm{~m}$ vertical resolution), EDO Western side-scan sonar $(100 \mathrm{kHz})$ with a range of $100 \mathrm{~m}$. The shallow seismic data were collected simultaneous and the filtered echoes were recorded on analog tape (side-scan sonar data excluded) and printed by graphic recorders (EPC and Klein). All seismic profiles have been depth converted by assuming a sediment sound velocity of $1700 \mathrm{~m} / \mathrm{s}$.

The seismic data from the surveys in Hjelm Bugt were interpreted in a conventional way by correlating lithological data with seismic units without using any application of seismic stratigraphic principles. The interpretation of data from Fakse Bugt was carried out according to the principles applied in seismic sequence analysis, based on the depositional sequence stratigraphic model as suggested by Vail et al. (1977). The established shallow seismic sequences are non cyclic, often not water deposited sequences, or they may be related to local water-level changes only, covering depositional events in the order of 2000 years or less. Thus, although the time is different and depositional framework probably more complicated than accounted for in the Vail-model, the application of the sequence stratigraphic working scheme ensures a homogeneous interpretation of the seismic registrations and further more, it provides a base for establishing a stratigraphy and interpreting the depositional environment, plus determination of local water-level changes.

Lithological information has been obtained by using published descriptions of grab samples, gravity coring (Fredningsstyrelsen 1986) and vibrocorings (Fredningsstyrelsen 1977). Detailed vertical lithofacies were established, using the facies description method from Eyles et al. (1983).

\section{Hjelm Bugt: results and interpretation}

From previous investigations (Fredningsstyrelsen 1977) the following stratigraphy has been established. A subhorizontal pre-Quaternary Cretaceous chalk surface $25 \mathrm{~m}$ to $40 \mathrm{~m}$ B.S.L. is covered by Pleistocene deposits, mainly diamict. In the innermost part of Grønsund these are overlayered by glacial outwash deposits. Some not preconsolidated diamict deposits were observed in core material that were interpreted as late glacial creeping soil. Late glacial lake deposits are found in the shallow Grønsund area and interpreted as local ice lakes, while a major deposit of varved clay-silt in the central part of Hjelm Bugt is related to the Baltic Ice Lake. In the Grønsund area Holocene deposits include freshwater peat deposits predating marine sand and gravel deposits, while the central Hjelm Bugt area is characterized by fine grained sand and gyttja deposits.

The detailed shallow seismic investigations carried out in the Grønsund area (1986) (Fig. 3a) added some interesting details. A map of the sediment distribution of the sea bed in Grønsund (Fig. 3d) reveals post glacial, late glacial and glacial deposits. The bathymetric map (Fig. $3 \mathrm{~b}$ ) reveals a channel and bar morphology, indicating a highly dynamic recent marine environment in the sand depositional area. Late glacial (Baltic Ice Lake) stratified clay-sand (Fig. 3d) onlaps the glacial deposits close to 20 $\mathrm{m}$ below Sea-Level (B.S.L.). The seismic unit shows a parallel even internal reflector configuration mainly with a concordant upper surface, indicating the precence of glacial ice lake with a water surface at about $20 \mathrm{~m}$ (B.S.L.). The original glacial surface topography is not possible to reestablish because of late- and postglacial erosion and redeposition. However, by removing the lateand postglacial stratified deposits a modified topography of the surface left over by the melting Weichselian ice cap can be presented (Fig. 3c). The map shows a general NE-SW orientation of the depth curves interrupted by a valley structure underneath the present Grønsund channel.

Some indications of more detailed glacial morphology can be recognised in the marginal zone of the valley area, where NE-SW orientated ridges appear with peaks at 10 m (B.S.L.). A northeast - southwest orientated glacial diamict area (Figs $3 \mathrm{c}$ and $3 \mathrm{~d}$ ) forms an about $3 \mathrm{~km}$ broad zone characterised by series of ridges producing a "ribbed" pattern on the sea floor. The longitudinal direction of the ridges follows the general northeast - southwest orientated glacial morphology. In the northernmost part of the detailed surveyed area (Fig. 3a) shallow seismic profile L36 (Fig. 4) reveals that the hollows between the ridges are partly filled out by seismically transparant Holocene Marine Sand (HMS). The assymetric ridges are generally between $50 \mathrm{~m}$ and $200 \mathrm{~m}$ wide, about $5 \mathrm{~m}$ high and with an irregular spacing of $50-300 \mathrm{~m}$. Seismic 


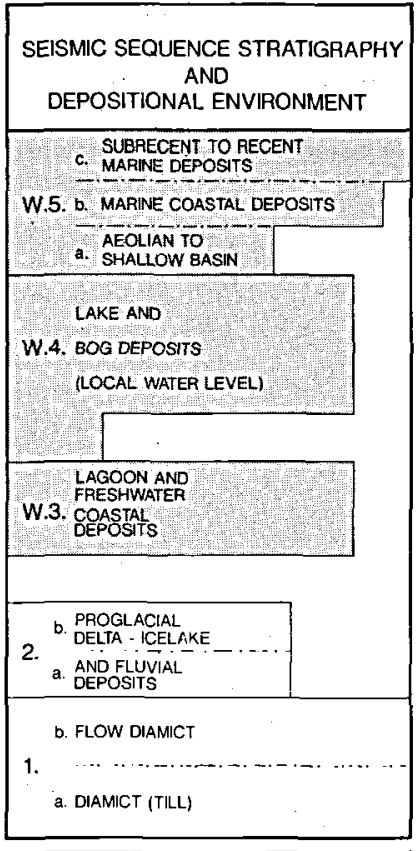

BEDROCK-CHALK

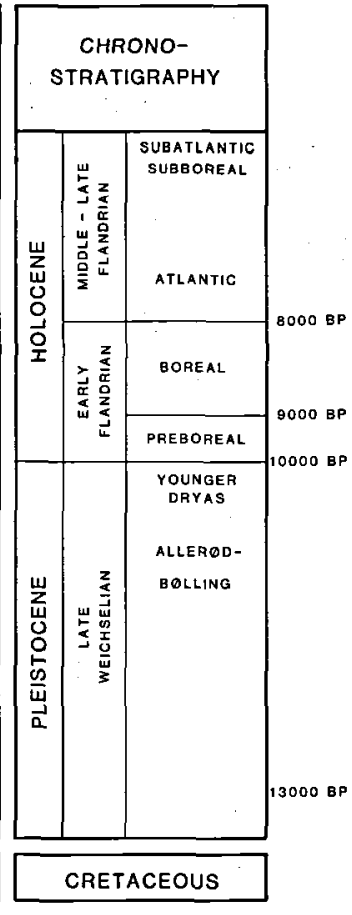

Fig. 6. Seismic sequence stratigraphy in Fakse Bugt and general chronostratigraphy. The sequences 1 . and 2 . are glacial deposits discussed in this paper while the sequences W.3. to W.5. (shaded area) represents younger sediments. Sequence boundaries are indicated by solid lines, while dot-and-dash lines indicates subdivision of sequences in seismic units.

facies analysis indicates, that the ridges are associated with convergent east dipping reflectors (8-10 degrees) with an erosive overlying unconformity and a diffuse transitional zone to underlying subhorizontal parallel reflectors. Lithological information from coring VC118 (Fig. 3a) shows that below approximately $0.8 \mathrm{~m}$ of Holocene marine sand and $1 \mathrm{~m}$ glacial diamict a unit of fat, sticky, solid clay is present (Fredningsstyrelsen 1977). The seismic reflection pattern of the diamict deposits is normally hummocky to reflection free, while stratified clay units show parallel reflection configuration. The dipping reflection pattern building up the ridges is interpreted to originate from stratified clay deposits contorted by glacial deformation to a level about $10 \mathrm{~m}$ below the sea floor.

In the westernmost marginal part of the ribbed moraine area a rim (Fig. 3d) consisting of a wedge shaped unit shows reflection free internal configuration. Coring revealing the existence of unloaded diamict (Fredningsstyrelsen 1977) and the existence of similarly well documented deposits in Fakse Bugt leads to the interpretation, that the wedge shaped unit represents supraglacial flow diamict deposits.

It is concluded that glacio-tectonic movements from southeast probably caused the development of the transverse ribbed moraine ridges. They resemble Rogen mo- raines (Shaw 1979) in their dimensions and internal structure. Rogen moraines are believed to form by inglacial thrusting and folding in zones of compressive flow.

\section{Fakse Bugt: results and interpretation}

In the Fakse Bugt survey area (Fig. 5a) it has been possible to compile a detailed seismic sequence stratigraphy. In this study area, 5 sequences are recognized representing Late Weichselian- and Holocene deposits, covering the pre-Quaternary bedrock (Fig. 6). The upper sequences W.3-W.5 (Fig. 6, shaded area) include sediments deposited in connection to the isostatic and eustatic competition following the deglaciation, while the sequences 1 and 2 are sediments deposited in direct connection to the deglaciation.

A structure map (Fig. 5b) of top of sequence 1 (Fig. 6) reveals the modified glacial topography of the investigation area. This surface is characterized by elongated ridges, interrupted by SE-NW orientated narrow valleys.

Comparing the glacial surface topography to the recent bathymetry, it is possible to recognize the morphological elements created in late- and postglacial times by processes other than glacial. The bathymetric map (Fig. 5c) reveals that the glacial surface has been leveled out, as sediment infill cover the major part of the glacial valleys. Furthermore new positive morphological elements have appeared as illustrated by the depth contour pattern of the $12 \mathrm{~m}$ and $10 \mathrm{~m}$ B.S.L isolines, which reveals elongated ridges. Detailed analysis of seismic data, supplemented by pollen analysis, 14-C dating and macrofossile analyses show that these features can be interpreted as barrier beach ridges and spit deposits formed during the Baltic Ice Lake maximum transgression and also during the Littorina transgression (Jensen 1992).

The glacial deposits dealt with in detail below can be subdivided in two sequences ( 1 and 2 ) and their respective subunits (Fig. 6). The sequences overlay Cretaceous sedimentary bedrock.

\section{Bedrock (Cretaceous chalk)}

Often seismic penetration did not reach the base of the Quaternary. Occasionally, however, the base of the quaternary sequences is recognized as acoustic basement characterised by a variable relief with deep valleys (Figs. $5,10 \mathrm{L126}$ ) displayed as a truncation of deformed stratified sequences below at a subsurface level of approximately $15-20 \mathrm{~m}$ B.S.L.

The lithological composition of the truncated sequence is Upper Cretaceous white chalck, which is the most dominating pre-Quaternary bedrock in the south-east- 

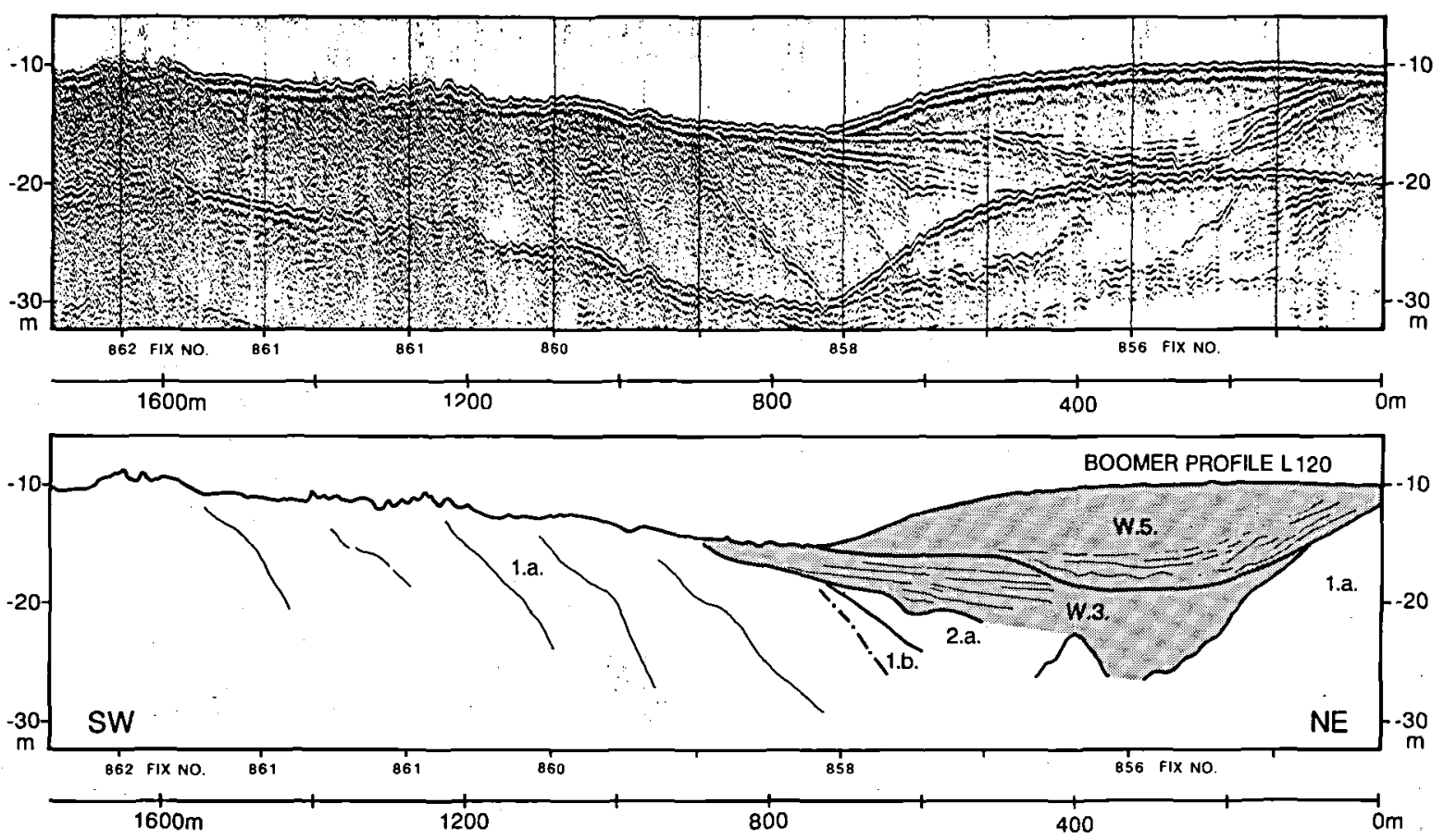

Fig. 7. Shallow seismic Boomer profile (EG\&G 0.8-16 kHz) and interpreted seismic sequences. Original seismic record L120 at top with interpretation below. The reflection pattern is interpreted using thick solid lines for sequence boundaries, dot-and-dash lines for separating seismic units and thin solid lines for internal reflection pattern. Location of the seismic record is shown in Fig. 5 and the seismic stratigraphy is outlined in Fig. 6.

ernmost part of Denmark (Bartmann and Christensen, 1975).

\section{Sequence 1. Glacial diamict}

The sequence is bounded by an upper erosional truncation, whereas the lower bounding surface is difficult to determine because of a dominating internal chaotic configuration. The sequence is divided in a lower unit a and an upper unit b. Basically, these show the same internal chaotic reflector configuration, but when they are found together, a distinct reflector can be observed separating the two units.

Unit 1.a forms the core of the glacial shoal areas (Hollændergrund and Gyldenløves Flak) found in Fakse Bugt (Fig. 5b). In the glacial areas a very irregular upper surface (unit 1.a) is often present. It is interpreted to originate from asymmetrical glacial ridges eroded by postglacial processes. These ridges can be recognized from one seismic line to the next. At the north-eastern part of Hollændergrund the internal chaotic configuration is disturbed by a number of NE dipping (5-10 degres) reflectors (Figs 5, $7 \mathrm{~L} 120$ and $8 \mathrm{~L} 121$ ) clearly associated with the ridges at the sea floor. These are interpreted as glacial thrust planes indicating a local ice pressure from
NE. This is supported by the longitudinal NW-SE direction of the ridges (Fig. 5d). The dimensions of the ridges are generally between $50-100 \mathrm{~m}$ wide, $2-4 \mathrm{~m}$ high and with an irregular spacing of $50-200 \mathrm{~m}$.

When regarding such a glaciological flow pattern from $\mathrm{NE}$, the shallow Hollændergrund lies just down-glacier from a NW-SE orientated depression system of somewhat similar size (Figs 5b, 7 L120 and 8 L121). A glacial feature like Hollændergrund is typical for glacial-thrust terrains (Moran 1980) consisting of hills and ridges composed of material that was dislocated by thrusting. Associated elongated depressions were the original locations of the thrust masses. Recently this type of glacial-thrusting has been named hill-hole pair landform (Aber 1988), typically with only short distance between the ice-thrust material and the corresponding depression. The lithology of the hill is mainly made up of pre-existing and contemporary diamict (unit 1.a) possibly together with bedrock material.

In the Gyldenløves Flak glacial area asymmetrical ridges comparable in their dimensions to the Hollændergrund ridges (Figs 5 and 9 L2) are partly preserved (Fig. 5d). They form a north-south orientated, about $5 \mathrm{~km}$ broad, zone. The strike of these ridges is approximatly $\mathrm{N}-\mathrm{S}$. The internal configuration is generally chaotic without visible dipping reflectors. Only a weak depression is present east of the glacial thrust terrain. Like in the 

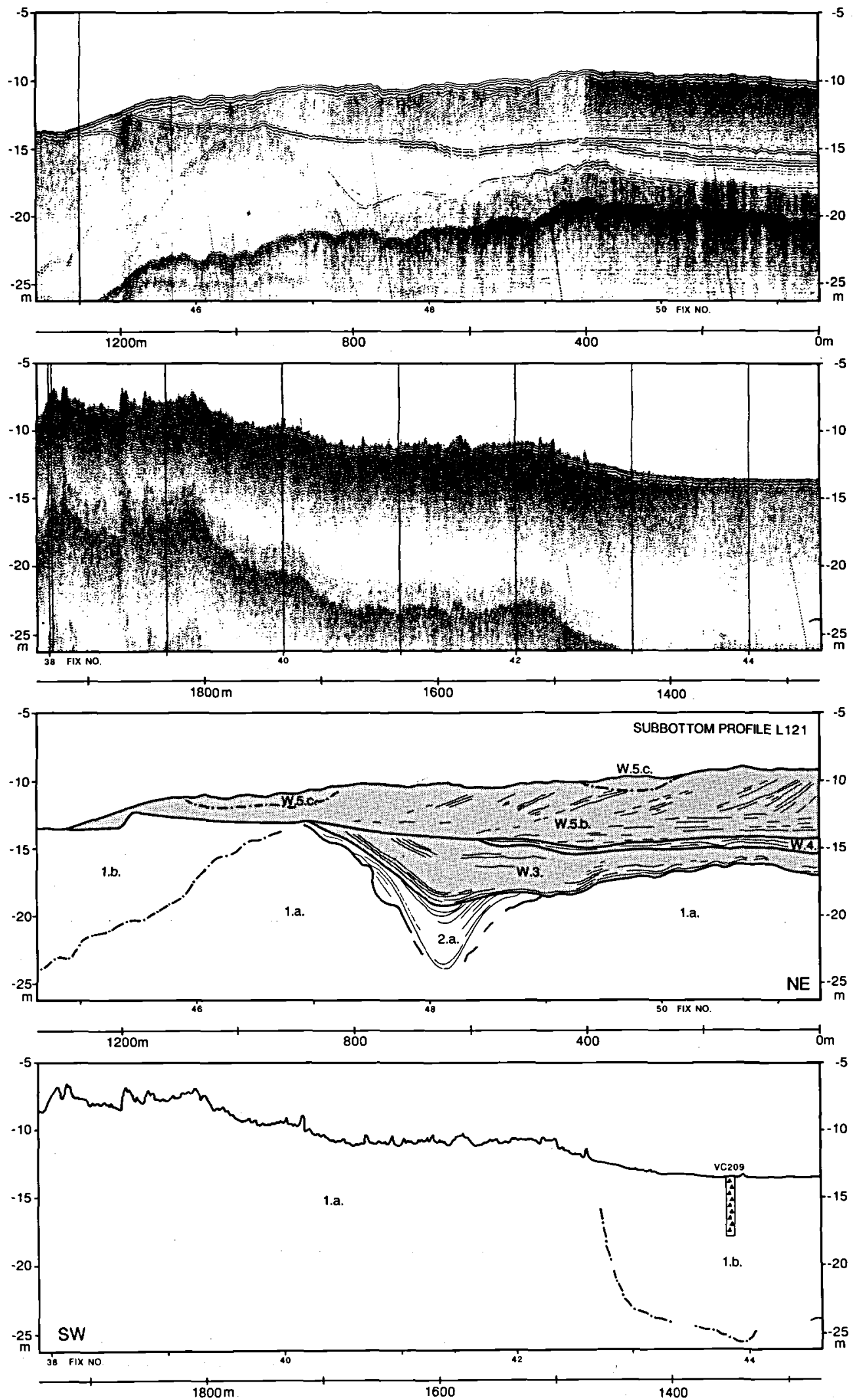

Fig. 8. Shallow seismic Subbottom profile (ORE $3.5 \mathrm{kHz}$ ) and interpreted seismic sequences. Original seismic record L121 at top with interpretation below. Vibrocore VC209 encounting diamict deposits is indicated. Location of the seismic record is shown in Fig. 5, the seismic stratigraphy is outlined in Fig. 6 and the signatures are described in Fig. 7. 

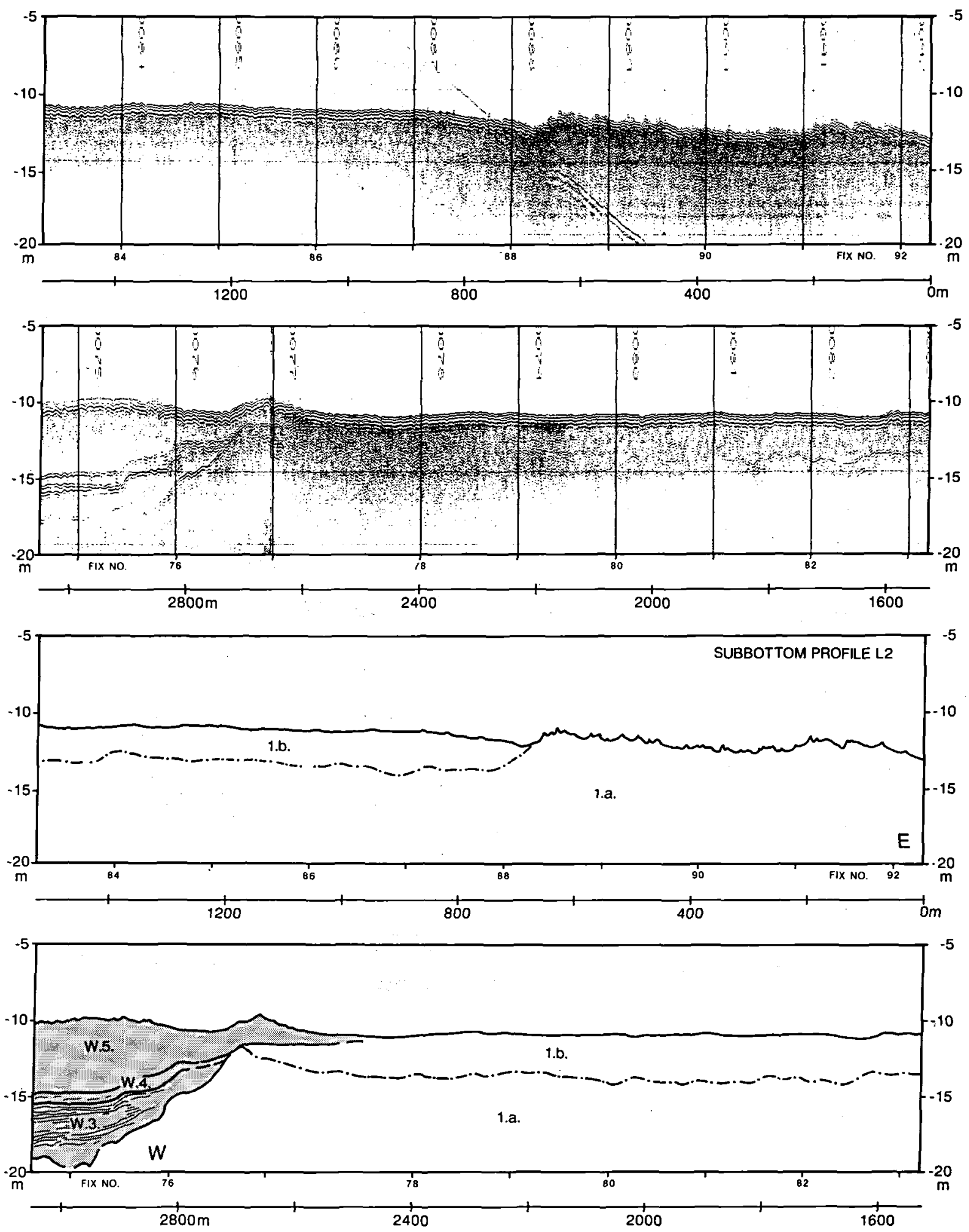

Fig. 9. Shallow seismic Subbottom profile (ORE $3.5 \mathrm{kHz}$ ) and interpreted seismic sequences. Original seismic record L2 at top with interpretation below. Location of the seismic record is shown in Fig. 5, the seismic stratigraphy is outlined in Fig. 6 and the signatures are described in Fig. 7. 

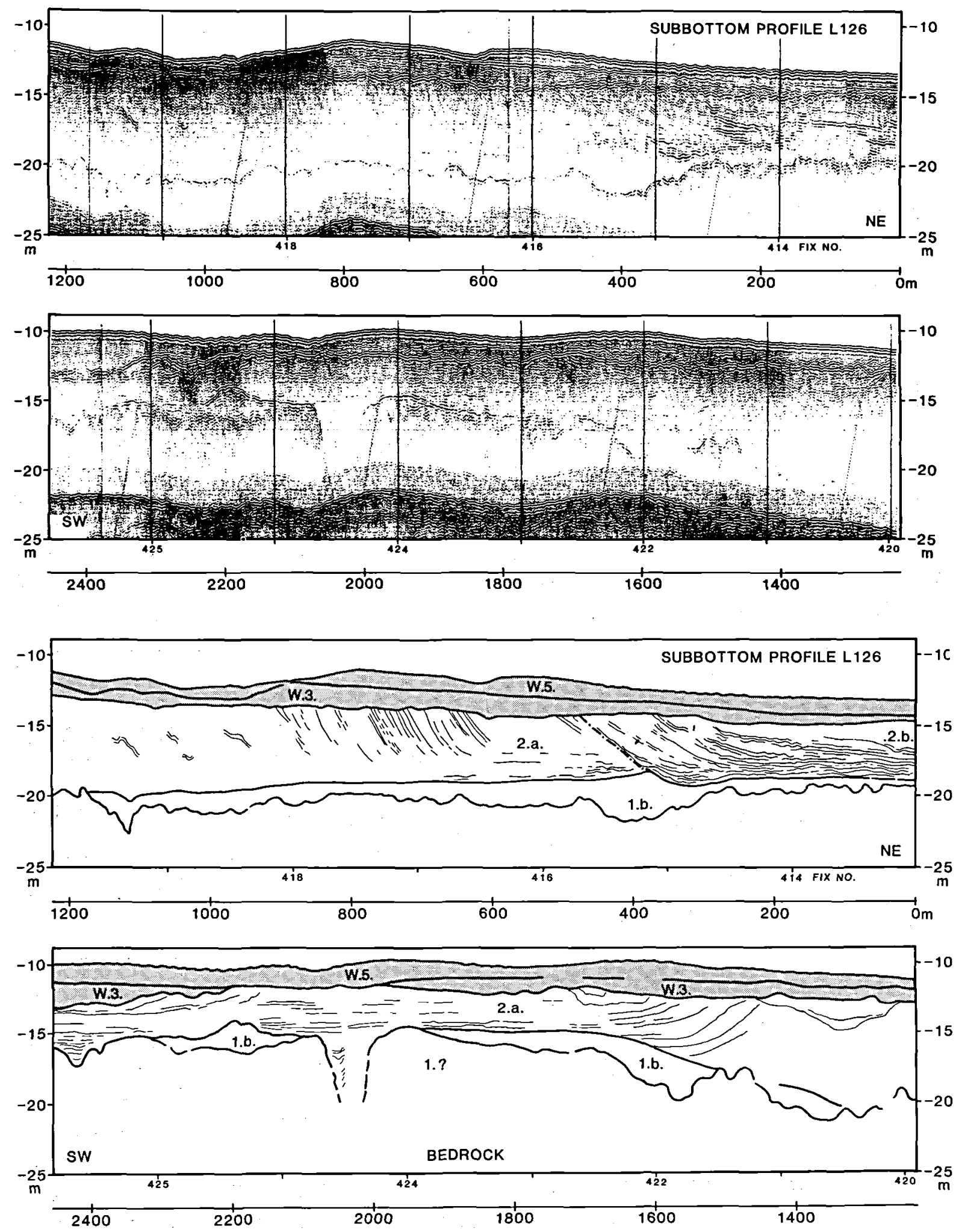

Fig. 10. Shallow seismic Subbottom profile (ORE $3.5 \mathrm{kHz}$ ) and interpreted seismic sequences. Original seismic record L126 at top with interpretation below. Location of the scismic record is shown in Fig. 5, the seismic stratigraphy is outlined in Fig. 6 and the signatures are described in Fig. 7. 


\section{SUBBOTTOM PROFILE L129}
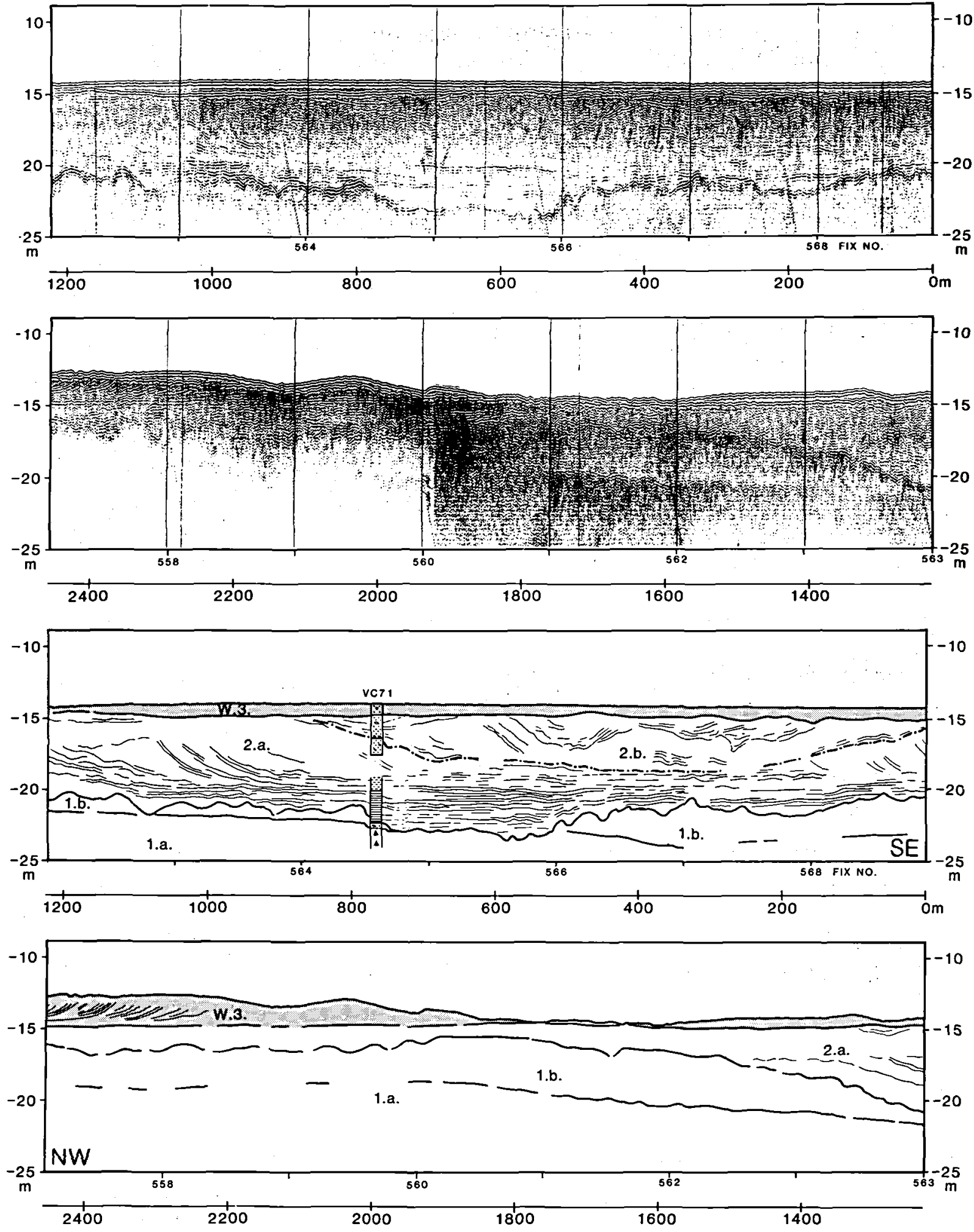

Fig. 11. Shallow seismic Subbottom profile (ORE $3.5 \mathrm{kHz}$ ) and interpreted seismic sequences. Original seismic record L129 at top with interpretation below. Vibrocore VC71 is indicated showing a lithology described in detail in Fig. 12. Location of the seismic record is shown in Fig. 5, the seismic stratigraphy is outlined in Fig. 6 and the signatures are described in Fig. 7. 

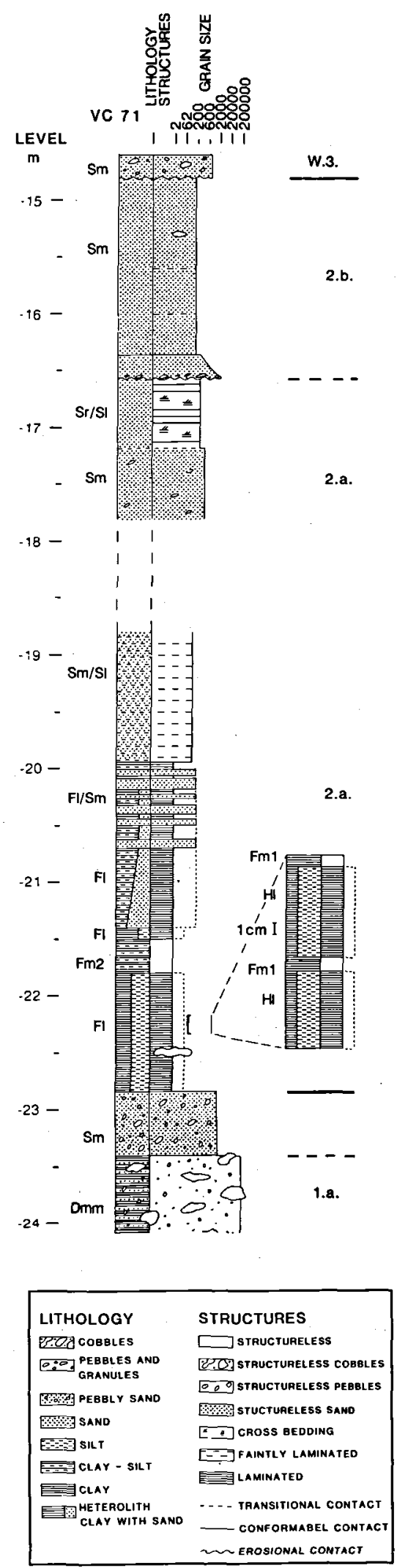

Fig. 12. Core log showing lithology and sedimentological structures in vibrocoring VC71. The correlation between lithofacies and seismically defined sequence boundaries is presented. Location of vibrocoring VC71 is shown in Fig. 5. Seismic sequence boundaries are marked by thick solid lines, seismic units are separated by dot-and-dash lines and sequence numbers 1.a. W.3. are indicated. Lithofacies are presented in a modified version of Eyles (1983): Dmm, matrix supported, massive diamict. Sm, massive sand. Sr, ripple cross bedded sand. Sl, horisontal laminated sand. Fl, fine laminated sand, silt, clay. Hl, laminated clay-silt, heterolithic. Fm1, massive clay. Fm2, massive clay-silt, normal graded.

Grønsund area the ridge gives a "ribbed" pattern interpreted as transverse ridges and are possibly related to Rogen moraine formation (Shaw 1979). They probably developed due to glacial advance from an eastern direction.

Unit 1.6 partly fills the depressions in-between the glacial thrust terrains (Figs $5 \mathrm{~b}$ and $5 \mathrm{~d}$ ). Just NE of Hollændergrund the contrast between unit $1 . a$ and $1 . b$ is very illustrative as the surface morphology changes most suddenly from the irregular surface of unit 1.a to the smooth surface of unit 1.b (Fig. $8 \mathrm{L121}$ ). A series of seismic lines reveals that the external form is trough fill with a maximum thickness of about $10 \mathrm{~m}, 500 \mathrm{~m}$ in width and $5 \mathrm{~km}$ in length with a direction of the trough parallel to the NW-SE orientated Hollændergrund ridges.

Another example of unit 1.b deposits is the area west of the Gyldenløves Flak (Figs 5a and 9 L2) showing the same change of surface morphology between unit 1.a and 1.b In this case the sequence is present in the form of sheet-like deposits, several meters thick, that cover a N-S orientated area of $5 \mathrm{~km} \times 2,5 \mathrm{~km}$.

The lithology (Fig. 8 VC209) can be characterized as not pre-consolidated (soft), matrix supported, massive to weakly stratified, clayey diamict containing sand, pebbles and cobbles.

Unit 1.b is interpreted as flow diamict deposited in the terminal region of the glacier in connection to the final Weichselian deglaciation. The depositional process most probably was subaerial sediment flow of mobilized meltout till filling out depressions in the dislocated glacial landscape. The low relief surface of unit 1.b indicates an extremely fluid diamict, which tend to flow down lowangle slopes. A less fluid diamict would have resulted in formation of a more hummocky moraine surface (Boulton 1972).

\section{Sequence 2. Proglacial, delta-ice lake and fluvial deposits}

The distribution of sequence 2 is limited to the trough shaped depressions west of Gyldenløves Flak (Fig. 5b). The upper bounding surface is truncated and overlaid by transgressive deposits. At the lower bounding surface the 
layers of the sequence is either concordant with the glacial deposits or onlap the surface of the glacial sequence 1 deposits (Figs 6 and 10 L126). Two units are distinguished i.e., a lower unit a and an upper unit b, separated by an erosive surface. This surface is created by a temporary break of a continued outbuilding of oblique, tangential, prograding clinoforms resulting in partly filling of the trough shaped basin (Figs. $10 \mathrm{~L} 126$ and $11 \mathrm{L129}$ ).

The lithological characteristics become apparent from the $10 \mathrm{~m}$ long vibrocore VC71 (Figs $11 \mathrm{~L} 129$ and 12). The lowermost meter of the core consists of matrix supported, massive, clayey and sandy diamict (Dmm) interpreted to be representative of seismic sequence 1 unit a. On top of this follows half a meter of massive, pebbly, coarse sand probably deposited at the border zone between sequence 1 and sequence 2 (Fig. 10 L126). Sequence 2 is represented by about $8 \mathrm{~m}$ of layered sand, silt and clay. Finaly the uppermost $0.2 \mathrm{~m}$ can be correlated to sequence W.3, consisting of massive, light grey, medium to coarse sand with a content of pebbles ( $\mathrm{Sm})$ and a lower erosive bedding surface. Seismic sequence W.3 is interpreted as freshwater transgressive deposits as outlined elsewhere (Jensen \& Stecher 1992).

The depositional environment of sequence 2 is revealed by the following description. The lowermost 6.2 $\mathrm{m}$ of sequence 2 (22.8-16.6 m B.S.L.) show a generally coarsing upwards unit from fine laminated clay and silt (Fl) to massive and cross laminated medium sand, a sedimentological unit that can be correlated with the seismic sequence 2 unit a. Detailed lithological descriptions show that the lowest $1.4 \mathrm{~m}(22.8-21.4 \mathrm{~m}$ B.S.L) are composed of rhythmites $(\mathrm{Fl})$ separated in $0.05-0.08 \mathrm{~m}$ thick multilaminated silt-clay beds with sharp contacts (heteroliths (HI)), and interrupted by about $0.01 \mathrm{~m}$ thick massive, grey-brown clay beds (Fm1). Usually a non erosive sharp contact can be observed between the two types of bedding. In addition, a "dropstone" is found 22.5 $\mathrm{m}$ B.S.L. and in the interval $21.8-21.5 \mathrm{~m}$ B.S.L. a $0.3 \mathrm{~m}$ thick massive, grey-brown, normal graded silt-clay bed (Fm2) is observed showing a clearly erosive lower bedding surface. In the interval 21.4-19.9 m B.S.L., fine laminated clay and very fine sand (Fl) are the dominating bedding type, showing similar detailed bedding as in the previously described $(\mathrm{Fl})$ bedding interval. However, in the uppermost part (20.7-19.9 m B.S.L.), 0.04-0.1 m thick massive, light grey, very fine grained sand beds increasingly interrupt the regularly laminated bedding. The following bedding type (19.9-18.8 m B.S.L.) is massive - laminated, light grey, silty very fine sand somewhat contorted during the coring process. A bad recovery of core material resulted in an interval (18.8-17.8 m B.S.L.) without preserved sediment, followed by about $0.6 \mathrm{~m}$ (17.8-17.2 m B.S.L.) massive (Sm), light grey, medium sand with a content of coarse sand and a few pebble clasts consisting of clay. The uppermost bedding type in seismic sequence 2 unit a $(17.2-16.6 \mathrm{~m} \mathrm{B.S.L.)}$ is ripple cross bedding (Sr) to horizontal laminated, (Sl) light grey, fine to medium sand showing a discontinuous non erosive lower bedding surface.

Seismic sequence 2 unit $b$ can be recognized in the core interval 16.6-14.8 m B.S.L.. The lowest $0.2 \mathrm{~m}$ consist of normal graded, massive, coarse to medium sand (Sm) containing pebbles and cobbles. A clearly erosive bedding contact is observed corresponding to the transitional zone between seismic units $2 . b$ and 2.a. The uppermost $1.6 \mathrm{~m}$ of sequence 2 , unit $b$, is composed of mainly massive, light grey, fine sand $(\mathrm{Sm})$ containing very few pebbles. The depositional environment of sequence 2 unit $\mathbf{a}$ and $\mathbf{b}$ is evident from the lithological facies association shown in vibrocore VC71. The combination of near lower boundary (2.a) subhorizontal reflectors (Figs $10 \mathrm{~L} 126$ and $11 \mathrm{L129}$ ) and multilaminated rhythmic sedimentation (Fig. 12) indicates a glaciolacustrine bottom set depositional environment.

The bottom set rhytmites in vibrocore VC71 are interpreted as mainly annual deposits (varvs) formed by stratified flow in the "summer" situation (Ashley 1985). These create sharp silt clay lamina contacts and irregular lamination ( $\mathrm{Hl})$, indicative of variable depositional conditions. The winter clay beds ( $\mathrm{Fm} 1)$ display a relatively constant thickness, reflecting the suspension settling time and basin depth. The normal graded silt-clay bed (Fm2) is interpreted as a single slump generated surge, interrupting the deposition of annual rhytmits. This is a well known facies relationship in glaciolacustrine deposits (Harrison 1975). The increasing content of fine sand interrupting the fine lamination, indicates a gradual increasing delta proximity. This is substantiated by the seismic evidence and lithology (Fig. 11 L129) as indicates a gradual change from bottom set deposits to lower delta forset deposits. A continuation of proximity leads to mid-delta forset deposits (Smith \& Ashley 1985) frequently represented by stacked climbing ripple-drift sequences (Gustavson et al. 1973). These are usually composed of fine sand, and possibly capped by clay drapes. Only limited lithological proof of mid-delta forset deposits could be found in vibrocore VC71 due to disturbance and bad recovery of core material. This core only reveals a presumably massive to crudely stratified silty very fine sand, followed by massive and ripple cross bedded sand. But dipping reflectors at the seismic profile L129 (Fig. 11) confirms the mid-delta depositional environment. The previously described boundary between sequence 2 unit $a$ and $b$ shows a marked erosional truncation (Figs $10 \mathrm{L1} 26$ and $11 \mathrm{L129}$ ) which is confirmed by the erosive bedding contact in vibrocore VC71 (Fig. 12). This internal erosional truncation in sequence 2 must be due to a sudden lowering of the glaciolacustrine water level, a well known event often happening in recent, ice dammed lakes. 


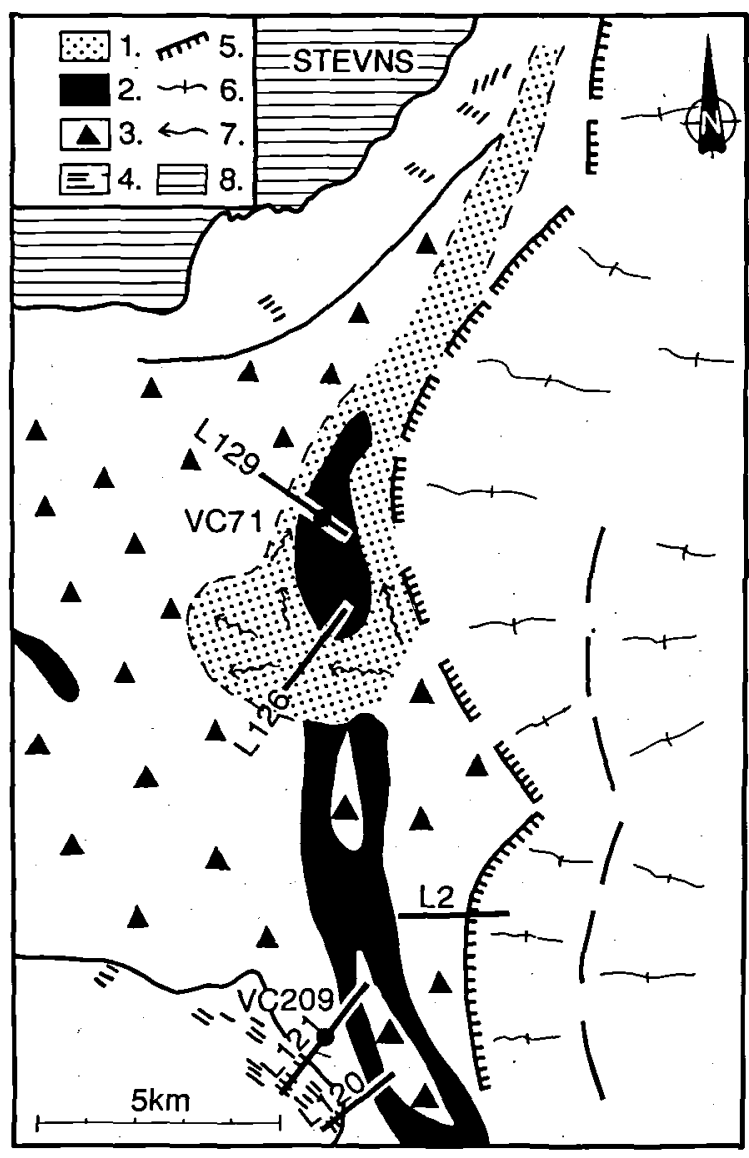

Fig. 13. Ice-marginal scenery in Fakse Bugt. Seismic profiles L2, L120, L121, L126, L129 and vibrocorings VC71, VC209 are indicated. 1: proglacial delta and fluvial deposits, 2: proglacial lake deposits, 3: flow diamict deposits, 4: diamict (till) showing transverse ridges. 5: ice-marginal position, 6: ice-flow lines, 7: paleo current directions, 8: present coast.

\section{Regional Late Weichselian deglaciation pattern.}

In the shallow waters of the Hjelm Bugt and Fakse Bugt the glacial shoals consist of a core of glacial-thrusted terrain, which shows a Ribbed moraine morphology resembling transverse ridges presumably associated with Rogen moraines (Lundqvist 1969, Shaw 1979). In the Hollændergrund area, Fakse Bugt, glacial thrusting has resulted in a development of a hill-hole pair landform (Aber 1989). The glacial-thrusted terrains are covered by low relief flow diamict deposits partly filling troughs and other irregularities in the pre-existing glacial landscape. This moraine landscape was then covered by proglacial delta - ice lake deposits. The lake may have been ice dammed.

The described deposits indicate an ice marginal scen- ery (Fig. 13) well known from Pleistocene ice sheets (Boulton 1972). Similar environmental conditions prevailed in south-eastern Sweden and a general correlation of ice recession data from the southern part of Sweden and Denmark, led to the conclusion that the ice resession had retreated to the Møn area around 14000-13000 BP (Houmark-Nielsen 1989, Lundqvist 1986). According to a deglaciation model by Lagerlund (1980) the southern part of Sweden and Denmark was affected by the same Late Weichselian readvance stage about 13300 BP. Swedish investigations of the deglaciation have revealed a zonal pattern with areas of hummocky moraine and transverse moraine (Möller 1987, Björck and Möller 1987). The hummocky moraine areas consist of melt-out till generally overlayered by flow diamict with a supraglacial origin. Investigations in modern arctic glaciers (Boulton 1972, Lawson 1982) demonstrate that the drainage conditions determine whether supraglacial diamict sheets will retain a hummocky or low relief surface. The latter tend to be deposited in topographic depressions with poor drainage conditions resulting in diamict, with a high water contents, able to flow on low-angle slopes.

The transverse moraine areas in Sweden are interpreted as melt-out tills formed subglacially as a combination of initial subglacial compressive flow followed by stagnation and melt-out. The data presented here in combination with periglacial conditions in the deglaciation period as reported by Johnsson (1986) indicate an ice sheet with a cold-based compressive marginal zone few kilometers wide (see also Aber 1982, Moran et al. 1980). Detailed investigations of transverse moraine areas in central Sweden (Shaw 1979) and Canada (Bouchard 1989) show that thrusting and folding due to inglacial compressive flow can involve subglacial sediments and underlying bedrock as well. It was also found that the major thrust planes typically are inclined about 5 degrees in the up-glacier direction. Obstacles of primary structural origin may cause the development of shear planes, leading to stacking of debris-laden ice slices (Bouchard 1989). The preservation of the transverse moraine areas can be explained by a limited late glacial climatic amelioration resulting in deglaciation under permafrost conditions. Marginal thinning of the ice sheet caused stagnation of basal debrisrich ice. Relatively slow melting of surface ice, created supraglacial melt-out till and flow diamict, allowing a more important basal melting and formation of subglacial melt-out till retaining the compressive imprint.

With such a model various earlier views on the deglaciation of Denmark need to be reconsidered. Kinetostratigraphic studies (Berthelsen 1973, 1979) indicate a number of Weichselian advances and recessions resulting in a complex till stratigraphy and structural set-up, while an area-wasting theory (Marcussen 1977) suggests only one Weichselian advance. The area-wasting deglaciation theory indicates a major surface ice melting resulting in a landscape completely dominated by flow diamict and stratified sediments. It only differs from the theory of Rogen moraine formation as proposed in this study in 


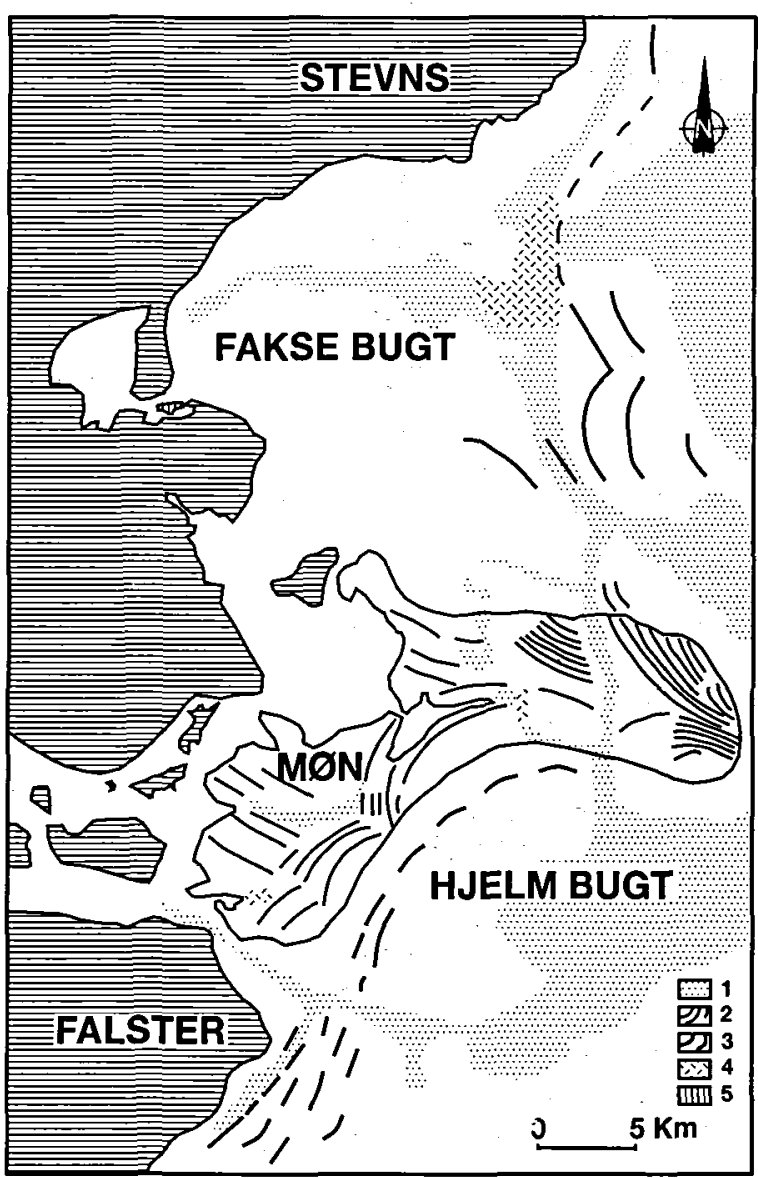

Fig. 14. Glacial imprints in the Møn area. 1: valleys. 2: hilldirections on the island of Møn. 3: transverse ridge directions in the shallow waters. 4: proximal meltwater deposits. 5: present land areas excl. Møn. Onshore data from Haarsted (1956).

view of the deglaciation climate. Besides this it is the opinion of the present author that the deglaciation by area-wasting is not contradicting to the possibility of a number of preexisting Weichselian advances and recessions. Kineto-stratigraphic investigations have given valuable information about compressive flow directions and till stratigraphy applied to a regional glacial stratigraphy. But probably the compressional flow and frontal melting model is too simple a solution, leading to erroneous stratigraphical conclusions.

The pairing of the Møns Klint section and a depression of appropriate size and shape a short distance up-stream in the glacial ice-flowe direction is tempting. Evidence of the expected hill-hole pair (Aber 1989) can be seen on a contour map (Fig. 15) showing the onshore morphology of Møn compared to the glacial surface morphology in the surrounding shallow waters. On this map a "horseshoe" like shaped depression can be located few kilometers east of the cliff section. The primary structural morphology may be the reason for the development of the

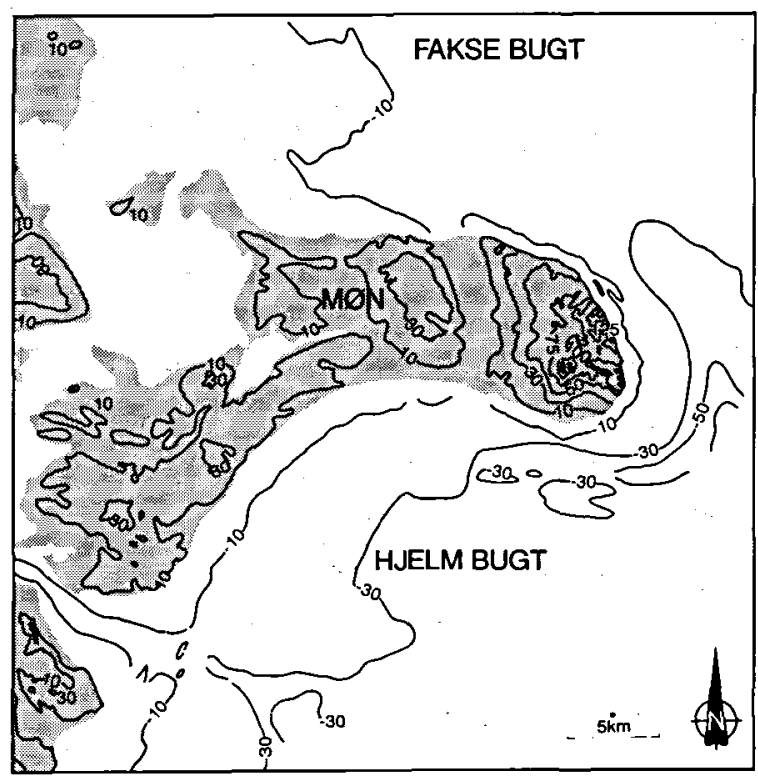

Fig. 15. Contour map showing the morphology in the onshore areas (shaded) and the morphology of the surface of the glacial deposits in adjacent shallow water areas.

glacial shear planes in the Møns Klint cliff section. This is tested by comparing the structural framework to glacial morphology revealing that the "horseshoe" shaped depression just east of Møn is placed at the margin of a positive basement block in the subsurface (Møn Block) (Pegrum 1984). Seismic survey data with intermediate penetration ( $0-1$ sec. two way time) carried out by $\mathrm{H}$. Lykke-Andersen, University of Århus, shows that normal faulting can be observed cutting through the Cretaceous bedrock east of Møn. From this it can be suggested that the Møn Block area possibly formed an obstacle that may have caused the development of large scale glacial thrusting.

\section{Conclusions}

The offshore glacial features, as for instance Rogen moraine ridges and proximal proglacial sediments, can be correlated with the glacial morphology found onshore on Møn (Fig. 14) (Haarsted 1956). The present data indicate a final Weichselian readvance with a glaciotectonic compression pattern formed between two ice lobes from a northeastern (Fakse Bugt) and a southeastern (Hjelm Bugt) direction. This conclusion clearly contradicts recent kineto-stratigraphical conclusions from the Møn area (Berthelsen 1979, Aber 1982) but not necessarily the glaciotectonic observations. Evidence of glacial thrusting from a northeasterly direction has been observed in the southern part of Møn. It was related to the Main Weichselian Advance (Berthelsen et al. 1977, Aber 1979) due to 
coverage by till showing a baltic composition and occasional thrusting from a southern direction. The northern section of Møns Klint cliff section is likewise ascribed to the Main Weichselian Advance with large scale southwestward thrusting. In contrast the southern section of Møns Klint is thrusted northward, whereas the central section shows a complex deformation pattern deformed by ice pushing from both north and south (Aber 1989). Berthelsen (1979) states that the northward thrusted southern section belongs to the Young Baltic Advance, which caused cutting and displacement of the older south-westward thrusted structures. It is the opinion of the present author that such a poly glacial model is not necessary to explain the deformation of the Møns Klint section. The ice lobe theory is sufficient to explain the Møns Klint thrust pattern as a result of competition in compression between two ice lobes. East of Møn a depression resembling Møns Klint in size and shape is observed. The morphological features are interpreted as a hill-hole pair possibly formed due to a Pre-quaternary obstacle (Møn Blok) which initiated the large scale glacial thrusting.

\section{Acknowledgements}

Financial support for the investigation was given by the National Forest and Nature Agency, the Danish Research Academy, and the Geological Survey of Denmark. An early version of the manuscript was critically reviewed by Antoon Kuijpers. The manuscript was further improved by the critical reading of Claus Andersen, Christian Christiansen, Holger Lykke-Andersen and Michael Houmark-Nielsen. Technical assistance was provided by Alice Rosenstand. I direct my best thanks to the above mentioned.

\section{Dansk sammendrag}

På Møn er den Pleistocæne udvikling beskrevet af adskillige geologer. Dette har resulteret $\mathrm{i}$ divergerende tolkninger af det glacialtektoniske hændelsesforløb. Dels en glacialmorfologisk model, hvor det glacialtektoniske kompressionsmønster er tolket som dannet mellem to islober, og dels en kinetostratigrafisk model, som henfører de glacialtektoniske dannelser til to adskilte hændelser.

Denne artikel beskriver shallow seismiske data indsamlet i Hjelm- og Fakse Bugt. Disse data er sammenlignet med eksisterende glacialtektoniske og morfologiske data fra land.

Konklusionen er, at Møns Klint blev dannet ved glacialtektonisk kompression, mellem to islober, $\mathrm{i}$ forbindelse med det afsluttende, Sen Weichsel recessive gletscherfremstød. Dette er i god overensstemmelse med den ge- nerelle opfattelse af Sen Weichsel deglaciationsmønstret i den sydlige del af Sverige.

Deglaciationsmønstret er karakteriseret af strøg med transverse rygge omgivet af lavninger udfyldt med flow till. De transverse rygge er tolket som Rogen Morain. Disse består af melt-out till, der er dannet subglacialt som en kombination af initial, subglacial, kompressiv deformation efterfulgt af stagnation og melt-out. Udfyldningerne med flow till er derimod af supraglacial oprindelse. I tilknytning til gletscherranden er der i Fakse Bugt dannet en lokal issø med en tilhørende deltaudbygning.

De indsamlede data viser, at tidligere divergerende afsmeltningsteorier, henholdsvis areal afsmeltning og frontal afsmeltning er for simple antagelser. Møns Klint og. en øst for liggende depression af sammenlignelig størrelse og form er tolket som et hill-hole pair system.

\section{References}

Aber, J. 1979: Kineto-stratigraphy at Hvideklint, Møn, Denmark and its regional significance. Bull. geol. Soc. Denmark 28, 81-93.

Aber, J. 1982: Model for glaciotectonism. Bull. geol. Soc. Denmark 30, 79-90.

Aber, J. 1985: The character of glaciotectonism. Geol. Mijnbouw 64, 389-395.

Aber, J. 1989: Spectrum of constructional glaciotectonic landforms. In: Goldthwait, R.P. \& Matsch, C.L. (eds): Genetic Classification of Glacigenic Deposits. A.A. Balkema, Rotterdam, 281-292.

Andersen, S.A. 1933: Det Danske Landskabs Historie. Danmarks Geologi i almenfatteligt omrids. Levin \& Munksgaard, Copenhagen, 274 pp.

Baartman, J.C. \& Christensen, O.B. 1975. Contributions to the interpretation of the Fennoscandian Border Zone. Danm. Geol. Unders., Ser. 2, 102, 1-47.

Berthelsen, A. 1973: Weichselian ice advances and drift successions in Denmark. Bull. Geol. Inst. Univ. Upps. 5, 21-29.

Berthelsen, A. 1978: The methodology of kineto-stratigraphy as applied to glacial geology. Bull. geol. Soc. Denmark 27, Special Issue, 25-38.

Berthelsen, A. 1979: Recumbent folds and boudinage structures formed by subglacial shear: an example of gravity tectonics. In: van der Linden, W.J.M. (ed.): Fixism, mobilism or relativism: Van Bemmelen's search for harmony - Geol. Mijnbouw 58, 253-260.

Berthelsen, A., Konradi, P. \& Petersen, K. S. 1977: Kvartære lagfølger og strukturer i Vestmøns klinter. Dansk geol. Foren., Årsskrift for 1976, 93-99.

Björck, S. \& Møller, P. 1987: Late Weichselian environmental history in southeastern Sweden during the deglaciation of the Scandinavian Ice Sheet. Quaternary Research 28, 1-37.

Bouchard, M.A. 1989: Subglacial landforms and deposits in central and northern Québec, Canada, with emphasis on Rogen morains. In: Menziens, J. \& Rosen, J. (eds): Subglacial Bedforms - Drumlines, Rogen Moraine and Associated Subglacial Bedforms, Sediment. Geol. 62, 293-308.

Boulton, G.S. 1972: Modern Artic glaciers as depositional models for former ice sheets. J. Geol. Soc. Lond. 128, 361-393.

Clemmensen, L.B. \& Houmark-Nielsen, M. 1981: Sedimentary features of a Weichselian glaciolacustrine delta. Boreas 10 , 229-245.

Eyles, N., Eyles, C.H. \& Miall, A.D. 1983: Lithofacies types and vertical profile; an alternative approach to the description 
and environmental interpretation of glacial diamict and diamictite sequences. Sedimentology 30, 393-410.

Fredningsstyrelsen 1977: Kortlægning af sømaterialer i Hjelm Bugt og Grønsund - Danish Min. Environment (Copenhagen), 46p. + app.

Fredningsstyrelsen 1986: Fakse Bugt. Råstoffer og fredningsinteresser. Danish Min. Environment (Copenhagen), 38p. + app.

Gripp, K. 1947: Jasmund und Möen, eine glacialmorphologische Untersuchung. Z. Erdkunde 1, 175-182.

Gustavson, T.C., Ashley, G.M. \& Boothryd, J.C. 1973: Depositional sequences in glaciolacustrine Deltas. In: Jopling, A.V. \& McDonalds, B.C. (eds): Glaciofluvial and glaciolacustrine sedimentation. Spec. Publ. Soc. Econ. Paleont. Miner. 23, 264-280.

Haarsted, V. 1956: De Kvartærgeologiske og geomorfologiske forhold på Món. Meddr. dansk geol. Foren. 13, 124-126.

Hansen, S. 1965: The Quaternary of Denmark. In: Rankama (ed.): The Quaternary. Vol. 1, Interscience Publishers, 1-90.

Hansen, S. \& Nielsen, A.V. 1960: Glacial Geology of southern Denmark. Guide to excurs. nos A44 \& C39. Int. Geol. Congr., XXI Sess., Norden 1960.

Harrison, S.S. 1975: Turbidite origin of glaciolacustrine sediments, Woodcock Lake, Pennsylvania. J. sedim. Petrol. 45, 738-744.

Hintze, V. 1937: Moens Klints Geologi. (Edited posthumously by E.L. Mertz and V. Nordmann). Copenhagen, C.A. Reitzels. $110 \mathrm{pp}$.

Houmark-Nielsen, M. 1981: Glacialstratigrafi i Danmark øst for Hovedopholdslinien. Dansk geol. Foren., Årsskrift for 1980, 61-76.

Houmark-Nielsen, M. 1987: Pleistocene stratigraphy and glacial history of the central part of Denmark. Bull. geol. Soc. Denmark 36, 1-189.

Houmark-Nielsen, M. 1988: Nyt om sidste istid. Klintholm, et nyt kvartærgeologisk nøgleprofil i østdanmark. Varv 4, 126138.

Houmark-Nielsen, M. 1989: Danmark i istiden - En tegneserie. Varv 2, 43-72.

Houmark-Nielsen, M. 1990: Kobbelgård \& Kraneled ved Klintholm. Nye nøgle-lokaliteter på østmøn. In: Petersen, K.S., Houmark-Nielsen, M., Kolstrup, E. \& Kronborg, C. (eds): Guide for Nordqua 90 i den centrale og Sydlige del af Danmark. Senpleistocanet. Intern rapport nr. 48. 1990. Danmarks Geologiske Unders $\varnothing$ gelse, Appendix 14.

Hyde, G. 1986. En glacialgeologisk unders $\emptyset$ gelse af klinterne på Nordøstmøn samt klinternes bagland. Unpublished thesis, Københavns Universitet, $115 \mathrm{p}$.

Jensen, J.B. 1985: Sen-Elster smeltevandsler - en mulig ledehorisont $\mathrm{i}$ det vestlige Jylland. Dansk geol. Foren., Årsskrift for 1984, 21-35.

Jensen, J.B. 1992: Late Pleistocene and Holocene depositional evolution in the shallow waters near the island of Møn, SE Denmark. Unpublished Ph. D. Thesis, Geological Survey of Denmark.

Jensen, J.B. \& Stecher, O 1992: Paraglacial barrier - lagoon development in the Late Pleistocene Baltic Ice Lake, Southwestern Baltic. Mar. Geol. 107, 81-101.

Johnsson, G. 1986: Different types of fossile frost fissures in south Sweden. Geologiska Föreningens i Stockholm Förhandlinger $108,167-175$.

Kolstrup, E. 1982a: Late-Glacial pollen diagrams from Hjelm and Draved Mose (Denmark) with a suggestion of the possibility of drought during the Early Dryas. Rev. Palaeobot. Palynol. 36, 35-63.
Kolstrup, E. 1982b: A pollen analytical investigation supported by an 18 O-record of Late Glacial lake deposits at Grænge (Denmark). Rev. Paleobot. Palynol. 36, 207-230.

Lagerlund, E. 1980: Lithostratigrafisk indelning av Västskånes Pleistocen och en ny glaciationsmodell för Weichsel. LUNDQUA Report 21, 120 p.

Lagerlund, E. 1987: An alternative Weichselian glaciation model, with special reference to the glacial history of Skåne, South Sweden. Boreas 16, 433-459.

Lawson, D.E. 1982: Mobilization, movement and depopsition of active subaerial sediment flows, Matanuska Glacier, Alaska. J. Geol. 90, 279-300.

Lundqvist, J. 1969: Problems of the so-caled Rogen moraine. Sver. Geol. Unders. C 648, 32 pp.

Lundqvist, J. 1986: Late Weichselian glaciation and deglaciation in Scandinavia. Quat. Sci. Rev. 5, 269-292.

Madsen, V., Jessen, K. \& Nordmann, V. 1928: Oversigt over Danmarks Geologi. Danm. geol. Unders. V. Rakke 4, 78142.

Marcussen, I. 1977: Deglaciation landscapes formed during the wasting of the late Middle Weichselian ice sheet in Denmark. Danm. geol. Unders. II Rakke, 110, 72pp.

Mikkelsen, V.M. 1949: Prast $\varnothing$ Fjord. The development of the postglacial vegetation and a contribution to the history of the Baltic Sea. Dansk Botanisk Arkiv 13, $171 \mathrm{p}$.

Milthers, V. 1909: Scandinavian Indicator-Boulders in Quaternary Deposits. Danm. geol. Unders. II Rxkke, 23, $153 \mathrm{pp}$.

Moran, S.R., Clayton, I., Hooke, R.LeB., Fenton, MM., \& Andriashek, L.D. 1980: Glacier-bed landforms of the prairie region of North America. Journal of Glaciology 25, 457-476.

Möller, P. 1987: Moraine morpohlogy, till genesis, and deglaciation pattern in the Åsnen area, south-central Småland, Sweden. LUNDQUA Thesis 20,146 pp.

Petersen, K.S. \& Konradi, P.B. 1974: Lithologiske og palæontologiske beskrivelser af profiler i kvartæret på Sjælland. Dansk geol. Foren., Årsskrift for 1973, 47-56.

Rasmussen, H.W. 1965: Strukturer dannet ved jordflydning, udglidning og issøtapning i kvartære smeltevandsaflejringer. Meddr dansk geol. Foren. 15, 470-485.

Rørdam, K. 1893: De geologiske Forhold i det nordøstlige Sjælland. Danm. geol. Unders. I Række, 3, 110 pp.

Rørdam, K. 1909: Geologi og jordbundstære, vol. I \& II. Nordisk Forlag. Copenhagen.

Shaw, J. 1979: Genesis of the Sveg tills and Rogen morains of central Sweden: a model of basal melt out. Boreas 8, 409426.

Sjørring, S. 1983: The glacial history of Denmark. In: Ehlers, J. (ed.): Glacial deposits in north-west Europe. A. A. Balkema, Rotterdam, 163-179.

Smith, N.D. \& Ashley, G. 1985: Proglacial lacustrine environment. In: Ashley, G.M., Shaw, J. \& Smith, N.D. (eds): Glacial sedimentary environments. Soc. Econ. Paleont. Miner. Short Course 16, 135-207.

Ussing , N.V. 1899: Danmarks Geologi i almenfatteligt Omrids. Danm. geol. Unders. III Række, 2, First edit., 372 p.

Vail, P.R., Mitchum, R.M., Jr., Todd, R.G.,Widmier, J.M., Thompson, S., III, Sangree, J.B. J.N., \& Hatlelid, W.G., 1977: Seismic stratigraphy and global changes of sea level. In: Clayton, C.E., (ed.): Seismic stratigraphy- Applications to Hydrocarbon Exploration. Am. Assoc. Pet. Geol. Mem. 26, 49-212.

Wentworth, C.K. 1922: A scale of grade class terms for clastic sediments. J. Geol. 30, 377-392. 